\title{
PHYSICAL AND CHEMICAL CHANGES IN JUVENILE AND MATURE WOOD OF SHIZOLOBIUM PARAHYBA CAUSED BY THERMAL MODIFICATION
}

\author{
Calonego FW*, Severo ETD, Sansígolo $\mathrm{CA}^{1}$ \& de Brito $\mathrm{AF}^{1}$ \\ ${ }^{1}$ FCA, UNESP, Fazenda Experimental Lageado s/n, Botucatu, 18610-307 Brazil \\ *fwcalonego@gmail.com
}

Submitted February 2019; accepted March 2020

\begin{abstract}
In the Brazilian Atlantic Forest, the pioneer species Schizolobium parahyba, known as guapuruvu, is a fastgrowing tree with potential for ecological restoration in forest management projects. However, an undesirable feature of this wood is the pronounced presence of juvenile wood leading to poor dimensional stability. This study evaluates the effect of various thermal modification intensities on the physicochemical properties of S. parahyba juvenile and mature wood. Boards sawn from 15-year-old trees were thermally modified at three different temperatures $\left(180,200\right.$ and $220{ }^{\circ} \mathrm{C}$ ). Thermal modification decreased the density (up to $9 \%$ ), moisture content (up to $9.1 \%$ ) and volumetric swelling (up to 54.1\%). For chemical properties, when the wood was submitted to thermal modification at $220{ }^{\circ} \mathrm{C}$, significant increase was detected in the respective extractive (up to 286.5\%) and lignin content (up to 41.7\%), and reduction in the holoceluloses (up to $25.0 \%$ ). It was demonstrated that basic density was not the most suitable parameter for evaluating the quality of thermally modified wood. The influence of thermal modification was equal in juvenile and mature wood.
\end{abstract}

Keywords: Guapuruvu, density of wood, dimensional stability, holocelluloses content, thermally modified wood

\section{INTRODUCTION}

Schizolobium parahyba (guapuruvu), a pioneer native species of Brazil, has high potential for ecological restoration projects in the Atlantic Forest (Engel \& Parrota 2001). It represents fast-growing trees, featuring light colored wood (Richter et al. 1974, Trianoski 2010, AthanásioHeliodoro 2015). Its commercial plantation is inexpressive, although very similar to $S$. amazonicum (paricá), which represents a large part of reforestation area $(90,000 \mathrm{ha})$ in the northern region of Brazil (IBÁ 2016).

Variation in the properties of wood occurs due to several factors, such as tree species, silviculture and especially the wood anatomy. Juvenile wood is also called pith wood or core wood which is formed near the tree center, displaying a cylindrical shape with a diameter almost uniform from the base to the top of the stem (Zobel \& Van Buijtenen 1989, Bao et al. 2001, Calonego et al. 2005). It differs from mature wood (outer wood) in chemical properties, fiber length, density and dimensional stability (Zobel \& Van Buijtenen 1989, Bao et al. 2001, Calonego et al. 2005, 2014, Lobão et al. 2012, Severo et al. 2012, 2016,) .
The fiber length in juvenile wood obtained from 15-year-old $S$. parahyba is $1.196 \mathrm{~mm}$, whereas in mature wood is $1.492 \mathrm{~mm}$. Anatomical characterisation shows that the juvenile wood is confined to a distance of $109.1 \mathrm{~mm}$ from the pith (Athanásio-Heliodoro 2015).

Richter et al. (1974) reported that the basic density of $S$. parahyba varies from 0.24 to $0.27 \mathrm{~g}$ $\mathrm{cm}^{-3}$. The basic density, maximum volumetric, and tangential and radial shrinkages of this wood are $0.39 \mathrm{~g} \mathrm{~cm}^{-3}, 10.03 \%, 8.31 \%$ and $1.72 \%$, respectively (Bortoletto Jr \& Belini 2002). According to Trianosky (2010), the basic density of this wood is $0.39 \mathrm{~g} \mathrm{~cm}^{-3}$, while the respective extractives, insoluble lignin and holocelluloses contents are $8.65 \%, 21.01 \%$ and $69.39 \%$, respectively.

The density at $12 \%$ moisture content in juvenile wood of $S$. amazonicum ranges between 0.312 and $0.544 \mathrm{~g} \mathrm{~cm}^{-3}$, whereas in mature wood, between 0.535 and $0.623 \mathrm{~g} \mathrm{~cm}^{-3}$ (Lobão et al. 2012). This physical property, maximum volumetric, and tangential, radial and longitudinal shrinkages in the juvenile wood of $S$. 
parahyba are $0.289 \mathrm{~g} \mathrm{~cm}^{-3}, 10.66 \%, 6.86 \%, 2.50 \%$ and $0.36 \%$, whereas in mature wood, they are $0.375 \mathrm{~g} \mathrm{~cm}^{-3}, 12.35 \%, 7.43 \%, 2.88 \%$ and $0.36 \%$, respectively (Athanásio-Heliodoro 2015).

Heat treatment of wood at high temperatures $\left(\sim 200{ }^{\circ} \mathrm{C}\right)$ or thermal modifications cause degradation of hemicelluloses and amorphous region of cellulose, contributing towards crystallinity of the polymer (Bhuiyan et al. 2000, Mburu et al. 2007, Esteves \& Pereira 2009, Bächle et al. 2010, Severo et al. 2012, 2016, Umar et al. 2016,). In addition, a cross-linkage between the lignin and the polymer occurs, which causes increase in biological resistance, decrease in hygroscopicity and improvement in dimensional stability (Mburu et al. 2007, Esteves \& Pereira 2009, Bächle et al. 2010, Calonego et al. 2012, 2014, Severo et al. 2012, 2016, Umar et al. 2016) . Moreover, the juvenile wood of both Pinus elliottii var. elliottii as Eucalyptus grandis is characterised by high lignin content when compared with mature wood, and consequently it presents an adverse effect on the chemical modification (Severo et al. 2012, Calonego et al. 2014). Hevea brasiliensis presents opposite behavior due to sugar content in the cell lumen of mature wood (Severo et al. 2016).

The aim of this study was to evaluate the effects of various intensities of thermal modification on the physicochemical properties of $S$. parahyba juvenile and mature wood.

\section{MATERIALS AND METHODS}

\section{Collection of materials}

Wood samples were obtained from four 15-yearsold S. parahyba (Fabaceae - Caesalpinioideae) trees, from the Lageado Farm of the State University of São Paulo, located in Botucatu $\left(22^{\circ}\right.$ $50^{\prime}$ S, $48^{\circ} 24^{\prime}$ W), São Paulo, Brazil. The trees were felled and sectioned into $2.5 \mathrm{~m}$ logs. The logs with diameters between 33 and $38 \mathrm{~cm}$ were cut into flat-sawn boards. Later, the boards were dried down to $10.0 \%$ moisture content in a dry kiln.

\section{Thermal modifications of boards}

A dried board from each tree was planed to 32-mm thickness and sawed into smaller pieces measuring $0.60 \mathrm{~m}$ in length. Regions with cracks and knots were discarded. A piece measuring $32 \times 180 \times 600 \mathrm{~mm}$ in size (tangential $\mathrm{x}$ radial $\mathrm{x}$ longitudinal) from each board was kept in its original condition (unmodified wood), and the other three pieces were thermally modified (thermally modified wood).

Parts of pieces were placed in an electric oven with a programmable controller and thermally modified in the Laboratory of Wood Drying and Preservation from UNESP, Botucatu, São Paulo, Brazil. The thermal modification started at an initial temperature of $100^{\circ} \mathrm{C}$ over a period of $14 \mathrm{~h}$ and then increased at $1.34^{\circ} \mathrm{C} \mathrm{min}{ }^{-1}$ up to $180^{\circ} \mathrm{C}$, and maintained over a period of $2.5 \mathrm{~h}$ under air atmosphere condition (Severo \& Calonego 2011). Same procedure was performed for thermal modification at final temperature of $200{ }^{\circ} \mathrm{C}$ and $220^{\circ} \mathrm{C}$. After thermal modification, the oven was turned off, and the wood pieces were conditioned in natural climate until they reached $30{ }^{\circ} \mathrm{C}$.

Standard specimens were sawn from all the pieces (unmodified and thermally modified) according to the method in ABNT NBR-7190 (1997) for physical characterisation of juvenile and mature wood. According to AthanásioHeliodoro (2015), the juvenile wood zone was defined as being located up to $109 \mathrm{~mm}$ from the pith, as identified by the fiber length of $S$. parahyba. Specimens of wood measuring $20 \times 30 \times$ $50 \mathrm{~mm}$ in size (tangential $\mathrm{x}$ radial $\mathrm{x}$ longitudinal) were removed approximately $20 \mathrm{~mm}$ from the pith and $20 \mathrm{~mm}$ from the bark. Each specimen was cut perfectly to produce tangential, radial and longitudinal directions and was then measured.

Although the ABNT NBR-7190 (1997) standard states that the necessary number of specimens to characterise physical properties of wood is six, twelve specimens were obtained from five boards to characterise each thermal modification (unmodified wood and thermally modified wood at $180{ }^{\circ} \mathrm{C}, 200{ }^{\circ} \mathrm{C}$ and $220{ }^{\circ} \mathrm{C}$ ), aggregating 48 specimens.

\section{Physical properties of the wood}

The unmodified and thermally modified specimens were placed in an oven at $103 \pm$ $2{ }^{\circ} \mathrm{C}$ and maintained until they reached $0 \%$ moisture content. Subsequently, the specimens were placed in a climatic chamber adjusted to $21{ }^{\circ} \mathrm{C}$ and $65 \%$ relative humidity ( $\left.\mathrm{RH}\right)$ until they reached equilibrium moisture content. The samples were then weighed, and their dimensions were measured by using a $0.01-\mathrm{g}$ accuracy balance and a $0.01-\mathrm{mm}$ accuracy 
micrometer. Following these measurements, the specimens were submerged in water until the cell walls were completely saturated. Then the dimensions of specimens were again measured and weighed. The evaluation of basic density, density in absolutely dry condition, density at equilibrium moisture content, equilibrium moisture content and maximum swellings were performed according to ABNT NBR-7190 (1997) standard.

\section{Chemical properties of the wood}

Samples of unmodified and thermally modified mature and juvenile wood were transformed into chips and then milled. The material used for chemical analysis was classified between 40 and 60 mesh. The extractives content was determined by extraction sequences with ethanol/toluene $1 / 2(\mathrm{v} / \mathrm{v})$, and ethanol and hot water (TAPPI T 12 wd-82 1999). The acid-insoluble Klason lignin (TAPPI T 222 om-98 1999), and holocelluloses (ASTM D-1104 1978) contents were determined in extractive-free wood.

To evaluate differences in physical and chemical properties, a Kolmogorov-Smirnov's normality test at $5 \%$ significance was performed. All variables had normal distribution. A parametric two-way test (ANOVA) at $5 \%$ significance was then performed taking into account the type of wood (two levels) and the thermal treatment (four levels), as well as Tukey's test at $5 \%$ significance for comparison of the means.

\section{RESULTS AND DISCUSSION}

Physical properties of thermally modified wood The basic density of unmodified $S$. parahyba was $0.235 \mathrm{~g} \mathrm{~cm}^{-3}$ for juvenile and $0.246 \mathrm{~g} \mathrm{~cm}^{-3}$ for mature wood. The density of these kinds of wood at equilibrium moisture content was 0.274 and $0.286 \mathrm{~g} \mathrm{~cm}^{-3}$, respectively (Table 1 ). The results of this study are similar to those presented by Bortoletto Jr. and Belini (2002), Richter et al. (1974) and Trianoski (2010). The densities of unmodified mature wood were not different than those of juvenile wood. This behavior is similar with the one showed by Athanásio-Heliodoro (2015), who related the non-influence of the type of wood on density of the species studied.

Basic density of $S$. parahyba wood did not change significantly by thermal modification, although it promoted a decrease in the oven-dry weight of specimens. However, it was found that the saturated volume of specimens presented a steep decrease with thermal modification. This fact is explained by the better influence of thermal modification on dimensional stability of wood than on weight loss. Calonego et al. (2012) reported that basic density is not the most suitable parameter for evaluating the quality of thermally modified wood.

Thermal modification decreased density significantly up to $8.8 \%$ and $9.1 \%$ and moisture content up to $9 \%$, in juvenile and mature wood. Thermal modification at $220{ }^{\circ} \mathrm{C}$ showed the greatest significant reductions in physical property. The juvenile and mature wood presented density at $9 \%$ of $0.250 \mathrm{~g} \mathrm{~cm}^{-3}$ and 0.260 $\mathrm{g} \mathrm{cm}^{-3}$, respectively. The reduction in density of thermally modified wood can be explained by the changes in chemical composition due to degradation of extractives and cell wall compounds, mainly sugars from hemicelluloses (Esteves \& Pereira 2009, Severo et al. 2016). The results were consistent with those obtained by Severo et al. (2012, 2016) and Calonego et al. (2014), who thermally modified the juvenile and mature wood from other species.

Table 1 shows that the respective equilibrium moisture contents (EMC) in juvenile and mature wood of unmodified S. parahyba were only $9.2 \%$ and $8.9 \%$ after acclimatization at $21^{\circ} \mathrm{C}$ and $65 \%$ RH. According to USDA (1999) these lower values in EMC can be attributed to the phenomenon known as hysteresis.

The EMC of mature wood was significantly smaller than that of juvenile wood. This is a result of the lower cell wall thickness of fibers from juvenile wood, which facilitates the diffusion of moisture in wood (Zobel and Van Buijtenen, 1989Calonego et al. 2005, Severo et al. 2012).

The current study also showed that thermal modification from $180{ }^{\circ} \mathrm{C}$ to $220{ }^{\circ} \mathrm{C}$ promoted significant EMC reductions up to $51.1 \%$ and $42.7 \%$ in juvenile and mature wood from $S$. parahyba. Similar improvements were cited for thermally modified wood of other species (Mburu et al. 2007, Bächle et al. 2010, Severo et al. 2012, Calonego et al. 2012, 2014,). The greatest weight loss in mature wood due to thermal modification explains the smaller reduction in EMC. Chemical changes lead to higher lignin reactivity with formation of crosslinks, leading to less absorption of water, which explains the decrease of EMC (Mburu et 
Table 1. Densities and equilibrium moisture content of thermally modified Schizolobium parahyba juvenile and mature wood

\begin{tabular}{|c|c|c|c|c|c|c|c|c|}
\hline \multirow{3}{*}{$\begin{array}{l}\text { Thermal } \\
\text { modification }\end{array}$} & \multirow{3}{*}{$\mathrm{N}$} & \multicolumn{7}{|c|}{ Basic density $\left(\mathrm{g} \mathrm{cm}^{-3}\right)$} \\
\hline & & \multicolumn{3}{|c|}{ Juvenile wood } & \multicolumn{3}{|c|}{ Mature wood } & \multirow[b]{2}{*}{$\begin{array}{c}\text { Red. } \\
\text { or (Inc.) }(\%)\end{array}$} \\
\hline & & $\mathrm{CV}$ & Average & $\begin{array}{c}\text { Red. or } \\
\text { (Inc.) }(\%)\end{array}$ & $\mathrm{CV}$ & Average & $\begin{array}{c}\text { Red. or } \\
\text { (Inc.) }(\%)\end{array}$ & \\
\hline Unmodified & 12 & 9.6 & $0.235 \mathrm{ab}$ & - & 12.0 & $0.246 \mathrm{ab}$ & - & $(4.7)^{\mathrm{NS}}$ \\
\hline $180^{\circ} \mathrm{C}$ & 12 & 4.5 & $0.246 \mathrm{a}$ & $(4.7)$ & 7.1 & $0.259 \mathrm{a}$ & $(5.3)$ & $(5.3)^{\mathrm{NS}}$ \\
\hline $200^{\circ} \mathrm{C}$ & 12 & 10.9 & $0.239 \mathrm{~b}$ & $(1.7)$ & 6.5 & $0.234 \mathrm{~b}$ & 4.9 & $2.1^{\mathrm{NS}}$ \\
\hline $220^{\circ} \mathrm{C}$ & 12 & 11.6 & $0.232 \mathrm{~b}$ & 1.3 & 4.3 & $0.240 \mathrm{~b}$ & 2.4 & $(3.4)^{\mathrm{NS}}$ \\
\hline
\end{tabular}

\begin{tabular}{|c|c|c|c|c|c|c|c|c|}
\hline \multirow{3}{*}{$\begin{array}{c}\text { Thermal } \\
\text { modification }\end{array}$} & \multirow{3}{*}{$\mathrm{N}$} & \multicolumn{7}{|c|}{ Density at $9 \%$ moisture content $-21^{\circ} \mathrm{C}$ e $65 \% \mathrm{RH}\left(\mathrm{g} \mathrm{cm}^{-3}\right)$} \\
\hline & & \multicolumn{3}{|c|}{ Juvenile wood } & \multicolumn{3}{|c|}{ Mature wood } & \multirow[b]{2}{*}{$\begin{array}{c}\text { Red. } \\
\text { or (Inc.) }(\%)\end{array}$} \\
\hline & & $\mathrm{CV}$ & Average & $\begin{array}{c}\text { Red. or } \\
\text { (Inc.) }(\%)\end{array}$ & $\mathrm{CV}$ & Average & $\begin{array}{c}\text { Red. or } \\
\text { (Inc.) }(\%)\end{array}$ & \\
\hline Unmodified & 12 & 9.6 & $0.274 \mathrm{ab}$ & - & 12.0 & $0.286 \mathrm{ab}$ & - & $(4.4)^{\mathrm{NS}}$ \\
\hline $180{ }^{\circ} \mathrm{C}$ & 12 & 4.6 & $0.281 \mathrm{a}$ & $(2.6)$ & 5.8 & $0.301 \mathrm{a}$ & $(5.2)$ & $(7.1)^{\mathrm{NS}}$ \\
\hline $200^{\circ} \mathrm{C}$ & 12 & 10.8 & $0.267 \mathrm{bc}$ & 2.6 & 6.6 & $0.262 \mathrm{bc}$ & 8.4 & $1.9^{\mathrm{NS}}$ \\
\hline $220^{\circ} \mathrm{C}$ & 12 & 11.7 & $0.250 \mathrm{c}$ & 8.8 & 4.5 & $0.260 \mathrm{c}$ & 9.1 & $(4.0)^{\mathrm{NS}}$ \\
\hline
\end{tabular}

\begin{tabular}{|c|c|c|c|c|c|c|c|c|}
\hline \multirow{3}{*}{$\begin{array}{c}\text { Thermal } \\
\text { modification }\end{array}$} & \multirow{3}{*}{$\mathrm{N}$} & \multicolumn{7}{|c|}{ Equilibrium woisture Content at $21^{\circ} \mathrm{C}$ e $65 \% \mathrm{RH}(\%)$} \\
\hline & & \multicolumn{3}{|c|}{ Juvenile wood } & \multicolumn{3}{|c|}{ Mature wood } & \multirow{2}{*}{$\begin{array}{c}\text { Red. } \\
\text { or (Inc.) }(\%)\end{array}$} \\
\hline & & $\mathrm{CV}$ & Average & $\begin{array}{l}\text { Red. } \\
(\%)\end{array}$ & $\mathrm{CV}$ & Average & $\begin{array}{l}\text { Red. } \\
(\%)\end{array}$ & \\
\hline Unmodified & 12 & 1.9 & $9.2 \mathrm{a}$ & - & 1.3 & $8.9 \mathrm{a}$ & - & $3.3 *$ \\
\hline $180^{\circ} \mathrm{C}$ & 12 & 3.1 & $7.7 \mathrm{~b}$ & 16.3 & 1.5 & $7.7 \mathrm{~b}$ & 13.5 & $0.0^{\mathrm{NS}}$ \\
\hline $200^{\circ} \mathrm{C}$ & 12 & 4.7 & $6.6 \mathrm{c}$ & 28.3 & 5.6 & $6.7 \mathrm{c}$ & 24.7 & $1.5^{\mathrm{NS}}$ \\
\hline $220^{\circ} \mathrm{C}$ & 12 & 3.8 & $4.5 \mathrm{~d}$ & 51.1 & 7.7 & $5.1 \mathrm{~d}$ & 42.7 & $13.3 *$ \\
\hline
\end{tabular}

where N - repeat number of samples, CV - coefficient of variation, Red. - reduction, Inc. - increase. RH relative humidity; average followed by the same letters in same column denote significant difference by Tukey test at probability $95 \%$ between thermal modifications; * within rows denote significant difference by $\mathrm{F}$ test at probability $95 \%$ between type of wood; same letters in same column and ${ }^{\mathrm{NS}}$ within rows denote non-significant difference

al. 2007, Esteves and Pereira 2009, Bächle et al. 2010).

The volumetric, tangential, radial and axial swelling in juvenile wood from unmodified S. parahyba was $9.67,6.63,2.45$ and $0.40 \%$, respectively. In mature wood, the respective swellings were 10.26, 7.26, 2.49 and $0.30 \%$, respectively (Table 2 ). The axial swelling of mature wood from unmodified material is different from that of juvenile wood, whereas other swellings are not different in both types of wood. It was found that the axial swelling of juvenile wood was greater $(25.0 \%)$ than mature wood. The results were consistent with previous studies on the swellings of unmodified S. amazonicum and dimensional stability of unmodified $S$. parahyba (Bortoletto Jr. and Belini 2002, Melo et al. 2013, Athanásio-Heliodoro 2015). Several authors explained that longitudinal swelling can be greater in juvenile wood because the wood has greater microfibril angles when compared with mature wood (Zobel \& Van Buijtenen 1989, Bao et al. 2001).

The effect of thermal modification on dimensional stability of $S$. parahyba wood is shown in Table 2. The results show that juvenile wood thermally modified from $180{ }^{\circ} \mathrm{C}$ to $220{ }^{\circ} \mathrm{C}$ had significant reductions of up to 54.1, 55.2, 46.9 , and $67.5 \%$ in volumetric, tangential, radial and axial linear swellings, when compared with 
Table 2. Swellings of thermally modified Schizolobium parahyba juvenile and mature wood

\begin{tabular}{|c|c|c|c|c|c|c|c|c|}
\hline \multirow{3}{*}{$\begin{array}{c}\text { Thermal } \\
\text { modification }\end{array}$} & \multirow{3}{*}{$\mathrm{N}$} & \multicolumn{7}{|c|}{ Maximum volumetric swelling (\%) } \\
\hline & & \multicolumn{3}{|c|}{ Juvenile Wood } & \multicolumn{3}{|c|}{ Mature Wood } & \multirow{2}{*}{$\begin{array}{c}\text { Red. } \\
\text { or (Inc.) }(\%)\end{array}$} \\
\hline & & $\mathrm{CV}$ & Average & $\begin{array}{c}\text { Red. or } \\
\text { (Inc.) }(\%)\end{array}$ & $\mathrm{CV}$ & Average & $\begin{array}{c}\text { Red. or } \\
\text { (Inc.) }(\%)\end{array}$ & \\
\hline Unmodified & 12 & 15.0 & $9.67 \mathrm{a}$ & - & 14.0 & $10.26 \mathrm{a}$ & - & $(6.1)^{\mathrm{NS}}$ \\
\hline $180^{\circ} \mathrm{C}$ & 12 & 3.5 & $9.07 \mathrm{~b}$ & 6.2 & 4.6 & $9.11 \mathrm{~b}$ & 11.2 & $(0.4)^{\mathrm{NS}}$ \\
\hline $200^{\circ} \mathrm{C}$ & 12 & 4.7 & $7.34 \mathrm{c}$ & 24.1 & 5.6 & $7.08 \mathrm{c}$ & 31.0 & $3.5^{\mathrm{NS}}$ \\
\hline $220^{\circ} \mathrm{C}$ & 12 & 3.8 & $4.44 \mathrm{~d}$ & 54.1 & 13.5 & $4.99 \mathrm{~d}$ & 51.4 & $(12.4)^{\mathrm{NS}}$ \\
\hline \multirow{3}{*}{$\begin{array}{c}\text { Thermal } \\
\text { modification }\end{array}$} & \multirow{3}{*}{$\mathrm{N}$} & \multicolumn{7}{|c|}{ Maximum tangential swelling $(\%)$} \\
\hline & & \multicolumn{3}{|c|}{ Juvenile wood } & \multicolumn{3}{|c|}{ Mature wood } & \\
\hline & & $\mathrm{CV}$ & Average & $\begin{array}{c}\text { Red. or } \\
\text { (Inc.) }(\%)\end{array}$ & $\mathrm{CV}$ & Average & $\begin{array}{c}\text { Red. or } \\
\text { (Inc.) }(\%)\end{array}$ & $\begin{array}{c}\text { Red. } \\
\text { or (Inc.) }(\%)\end{array}$ \\
\hline Unmodified & 12 & 18.3 & $6.63 \mathrm{a}$ & - & 19.4 & $7.26 \mathrm{a}$ & - & $(9.5)^{\mathrm{NS}}$ \\
\hline $180^{\circ} \mathrm{C}$ & 12 & 8.4 & $6.05 \mathrm{~b}$ & 8.8 & 7.0 & $6.31 \mathrm{~b}$ & 13.1 & $(4.3)^{\mathrm{NS}}$ \\
\hline $200{ }^{\circ} \mathrm{C}$ & 12 & 5.7 & $5.26 \mathrm{c}$ & 20.7 & 9.7 & $5.05 \mathrm{c}$ & 30.4 & $4.0^{\mathrm{NS}}$ \\
\hline $220^{\circ} \mathrm{C}$ & 12 & 8.0 & $2.97 \mathrm{~d}$ & 55.2 & 16.4 & $3.30 \mathrm{~d}$ & 54.5 & $(11.1)^{\mathrm{NS}}$ \\
\hline \multirow{3}{*}{$\begin{array}{l}\text { Thermal } \\
\text { modification }\end{array}$} & \multirow{3}{*}{$\mathrm{N}$} & \multicolumn{7}{|c|}{ Maximum radial swelling (\%) } \\
\hline & & \multicolumn{3}{|c|}{ Juvenile wood } & \multicolumn{3}{|c|}{ Mature wood } & \\
\hline & & $\mathrm{CV}$ & Average & $\begin{array}{l}\text { Red. } \\
(\%)\end{array}$ & $\mathrm{CV}$ & Average & $\begin{array}{l}\text { Red. } \\
(\%)\end{array}$ & $\begin{array}{c}\text { Red. } \\
\text { or (Inc.) }(\%)\end{array}$ \\
\hline Unmodified & 12 & 55.5 & $2.45 \mathrm{a}$ & - & 12.0 & $2.49 \mathrm{a}$ & - & $(1.6)^{\mathrm{NS}}$ \\
\hline $180^{\circ} \mathrm{C}$ & 12 & 19.9 & $2.54 \mathrm{a}$ & $(3.7)$ & 7.9 & $2.34 \mathrm{a}$ & 6.0 & 7.9 NS \\
\hline $200{ }^{\circ} \mathrm{C}$ & 12 & 7.2 & $1.77 \mathrm{~b}$ & 27.8 & 10.9 & $1.82 \mathrm{~b}$ & 26.9 & $(2.8)^{\mathrm{NS}}$ \\
\hline $220^{\circ} \mathrm{C}$ & 12 & 12.4 & $1.30 \mathrm{c}$ & 46.9 & 9.1 & $1.50 \mathrm{c}$ & 39.8 & $(15.4)^{\mathrm{NS}}$ \\
\hline \multirow{3}{*}{$\begin{array}{c}\text { Thermal } \\
\text { modification }\end{array}$} & \multirow{3}{*}{$\mathrm{N}$} & \multicolumn{7}{|c|}{ Maximum longitudinal swelling $(\%)$} \\
\hline & & \multicolumn{3}{|c|}{ Juvenile wood } & \multicolumn{3}{|c|}{ Mature wood } & \\
\hline & & $\mathrm{CV}$ & Average & $\begin{array}{l}\text { Red. } \\
(\%)\end{array}$ & $\mathrm{CV}$ & Average & $\begin{array}{l}\text { Red. } \\
(\%)\end{array}$ & $\begin{array}{c}\text { Red. } \\
\text { or (Inc.) }(\%)\end{array}$ \\
\hline Unmodified & 12 & 20.2 & $0.40 \mathrm{a}$ & - & 13.8 & $0.30 \mathrm{a}$ & - & $25.0 *$ \\
\hline $180^{\circ} \mathrm{C}$ & 12 & 33.0 & $0.31 \mathrm{~b}$ & 22.5 & 32.7 & $0.30 \mathrm{a}$ & 0.0 & $3.2^{\mathrm{NS}}$ \\
\hline $200{ }^{\circ} \mathrm{C}$ & 12 & 27.6 & $0.20 \mathrm{c}$ & 50.0 & 27.7 & $0.11 \mathrm{~b}$ & 63.3 & $45.0 *$ \\
\hline $220^{\circ} \mathrm{C}$ & 12 & 32.7 & $0.13 \mathrm{~d}$ & 67.5 & 33.2 & $0.13 \mathrm{~b}$ & 56.7 & $0.0^{\mathrm{NS}}$ \\
\hline
\end{tabular}

where N - repeat number of samples, CV - coefficient of variation, Red. - reduction, Inc. - increase; average followed by the same letters in same column denote significant difference by Tukey test at probability $95 \%$ between thermal modifications; * within rows denote significant difference by $\mathrm{F}$ test at probability $95 \%$ between type of wood; same letters in same column and ${ }^{\mathrm{NS}}$ within rows denote non-significant difference

unmodified wood. Thermally modified mature wood under the same temperature presented reductions of up to $51.4,54.5,39.8$ and $56.7 \%$ in the respective swellings.

Improvement of dimensional stability in thermally modified wood is a result of the increase in crystallinity and the width of crystallites due to degradation of hemicelluloses and free hydroxyl groups in the amorphous region of cellulose, and cross-linking of polymers of wood (Bhuiyan et al. 2000, Esteves and Pereira 2009, Bächle et al. 2010, Severo et al. 2012, 2016) . 
The influence of thermal modification on juvenile wood from $S$. parahyba was equal to mature wood. However, thermally modified Pinus and Eucalyptus wood presented an adverse effect on the modification of juvenile wood because of their high lignin content, compared with mature wood (Severo et al. 2012, Calonego et al. 2014). The results presented in this study also differed from Severo et al. (2016) who concluded that the influence of thermal modification at $220{ }^{\circ} \mathrm{C}$ on the properties of mature wood from $H$. brasiliensis was lower than in juvenile wood. The sugars and starches present in the cellular lumen periphery of the stem can delay thermal degradation of wood cell wall, and therefore maintain the matured rubberwood closer to its original condition.
In verifying the effects of thermal modification on the physical properties of $S$. parahyba wood, it was found that temperatures ranging up to 220 ${ }^{\circ} \mathrm{C}$ improved dimensional stability without loss of material through internal cracks. These results were similar to previous reports on thermally modified wood of other species (Bhuiyan et al. 2000, Mburu et al. 2007, Calonego et al. 2012, Severo et al. 2012).

\section{Chemical properties of thermally modified wood}

The extractive, lignin and holocelluloses contents of juvenile wood from unmodified $S$. parahyba were $1.78,25.32$ and $80.81 \%$, respectively, while

Table 3. Extractives, lignin and holocelluloses content of thermally modified Schizolobium parahyba juvenile and mature wood

\begin{tabular}{|c|c|c|c|c|c|c|c|c|}
\hline \multirow{3}{*}{$\begin{array}{l}\text { Thermal } \\
\text { modification }\end{array}$} & \multirow{3}{*}{$\mathrm{N}$} & \multicolumn{7}{|c|}{ Extractives content (\%) } \\
\hline & & \multicolumn{3}{|c|}{ Juvenile wood } & \multicolumn{3}{|c|}{ Mature wood } & \multirow{2}{*}{$\begin{array}{c}\text { Red. } \\
\text { or (Inc.) }(\%)\end{array}$} \\
\hline & & $\mathrm{CV}$ & Average & $\begin{array}{c}\text { Red. or } \\
\text { (Inc.) }(\%)\end{array}$ & $\mathrm{CV}$ & Average & $\begin{array}{c}\text { Red. or } \\
\text { (Inc.) }(\%)\end{array}$ & \\
\hline Unmodified & 4 & 24.8 & $1.78 \mathrm{a}$ & - & 37.4 & $3.25 \mathrm{a}$ & - & $(82.6)^{\mathrm{NS}}$ \\
\hline $180^{\circ} \mathrm{C}$ & 4 & 29.2 & $2.79 \mathrm{ab}$ & $(56.7)$ & 41.8 & $3.66 \mathrm{ab}$ & (12.6) & $(31.2)^{\mathrm{NS}}$ \\
\hline $200{ }^{\circ} \mathrm{C}$ & 4 & 12.3 & $3.61 \mathrm{~b}$ & (102.8) & 24.1 & $4.24 \mathrm{~b}$ & $(30.5)$ & $(17.5)^{\mathrm{NS}}$ \\
\hline $220^{\circ} \mathrm{C}$ & 4 & 5.9 & $6.88 \mathrm{c}$ & $(286.5)$ & 20.0 & $5.06 \mathrm{c}$ & $(55.7)$ & $26.5^{\mathrm{NS}}$ \\
\hline
\end{tabular}

\begin{tabular}{|c|c|c|c|c|c|c|c|c|}
\hline \multirow{3}{*}{$\begin{array}{l}\text { Thermal } \\
\text { modification }\end{array}$} & \multirow{3}{*}{$\mathrm{N}$} & \multicolumn{7}{|c|}{ Insoluble klason lignin content $(\%)$} \\
\hline & & \multicolumn{3}{|c|}{ Juvenile wood } & \multicolumn{3}{|c|}{ Mature wood } & \multirow{2}{*}{$\begin{array}{c}\text { Red. } \\
\text { or (Inc.) }(\%)\end{array}$} \\
\hline & & CV & Average & $\begin{array}{c}\text { Red. or } \\
\text { (Inc.) }(\%)\end{array}$ & $\mathrm{CV}$ & Average & $\begin{array}{c}\text { Red. or } \\
\text { (Inc.) }(\%)\end{array}$ & \\
\hline Unmodified & 4 & 3.0 & $25.32 \mathrm{a}$ & - & 5.3 & $22.58 \mathrm{a}$ & - & $10.8 *$ \\
\hline $180^{\circ} \mathrm{C}$ & 4 & 3.5 & $24.47 \mathrm{a}$ & 3.4 & 10.9 & $21.97 \mathrm{a}$ & 2.7 & $10.2 *$ \\
\hline $200{ }^{\circ} \mathrm{C}$ & 4 & 2.9 & $24.45 \mathrm{a}$ & 3.4 & 3.9 & $23.93 \mathrm{a}$ & $(6.0)$ & $2.1 *$ \\
\hline $220^{\circ} \mathrm{C}$ & 4 & 3.6 & $31.21 \mathrm{~b}$ & $(23.3)$ & 6.9 & $32.00 \mathrm{~b}$ & $(41.7)$ & $(2.5) *$ \\
\hline \multirow{3}{*}{$\begin{array}{c}\text { Thermal } \\
\text { modification }\end{array}$} & \multirow{3}{*}{$\mathrm{N}$} & \multicolumn{6}{|c|}{ Holocelluloses content (\%) } & \\
\hline & & \multicolumn{3}{|c|}{ Juvenile wood } & \multicolumn{3}{|c|}{ Mature wood } & \multirow{2}{*}{$\begin{array}{c}\text { Red. } \\
\text { or (Inc.) }(\%)\end{array}$} \\
\hline & & CV & Average & $\begin{array}{l}\text { Red. } \\
(\%)\end{array}$ & $\mathrm{CV}$ & Average & $\begin{array}{l}\text { Red. } \\
(\%)\end{array}$ & \\
\hline Unmodified & 4 & 2.2 & $80.81 \mathrm{a}$ & - & 3.2 & $80.59 \mathrm{a}$ & - & $0.3 *$ \\
\hline $180^{\circ} \mathrm{C}$ & 4 & 1.4 & $78.95 \mathrm{a}$ & 2.3 & 2.1 & $80.95 \mathrm{a}$ & $(0.5)$ & $(2.5) *$ \\
\hline $200{ }^{\circ} \mathrm{C}$ & 4 & 5.7 & $72.00 \mathrm{~b}$ & 10.9 & 4.1 & $74.62 \mathrm{~b}$ & 7.4 & $(3.6) *$ \\
\hline $220^{\circ} \mathrm{C}$ & 4 & 4.5 & $60.63 \mathrm{c}$ & 25.0 & 4.9 & $66.63 \mathrm{c}$ & 17.3 & $(9.9) *$ \\
\hline
\end{tabular}

where N - repeat number of samples, CV - coefficient of variation, Red. - reduction, Inc. - increase; average followed by the same letters in same column denote significant difference by Tukey test at probability $95 \%$ between thermal modifications; * within rows denote significant difference by $\mathrm{F}$ test at probability $95 \%$ between type of wood; same letters in same column and ${ }^{\mathrm{NS}}$ within rows denote non-significant difference 
in mature wood were $3.25,22.58$ and $80.59 \%$, respectively (Table 3 ). These results were similar to previous studies on hardwoods, in general, as well as S. parahyba (Fengel and Wegener 1989, Trianoski 2010).

The effect of thermal modification on the chemical properties of $S$. parahyba wood is shown in Tables 3. Thermal modification caused significant increase in extractives content for juvenile and mature wood (up to $286.5 \%$ and $55.7 \%$ respectively), and a significant decrease in holocelluloses content $(25.5 \%$ for juvenile wood and $17.3 \%$ for mature wood). The greatest effect for both juvenile and mature wood occurred at $220{ }^{\circ} \mathrm{C}$. It was assumed that the increase in extractives content during thermal modification was due to the degradation of holocelluloses.

Several other studies have shown that thermal modification of wood leads to hemicellulose degradation, resulting in an increase of the extractives and lignin contents (Esteves \& Pereira 2009, Bächle et al. 2010, Severo et al. 2012, 2016, Umar et al. 2016). A significant increase in lignin content for both juvenile $(23.3 \%)$ and mature wood $(41.7 \%)$ occurred with thermal modification at $220^{\circ} \mathrm{C}$. These results were similar to previous studies that reported a general trend, where the relative mass proportion of lignin increased with both elevated temperature and extended modification time, with a simultaneous decrease in sugar content (Mburu et al. 2007, Severo et al. 2012, 2016, Umar et al. 2016).

\section{CONGLUSIONS}

This study showed that thermal modification of $S$. parahyba wood decreased density at $9 \%$ moisture content (of up to $9.1 \%$ ) and volumetric swelling (up to $54.1 \%$ ). For chemical properties, significant increase was detected in the respective extractives (up to $286.5 \%$ ) and lignin contents (up to $41.7 \%$ ), and reduction in holoceluloses (up to $25.0 \%$ ), when the wood was submitted to thermal modification at $220^{\circ} \mathrm{C}$. The results demonstrated that basic density was not the most suitable parameter for evaluating the quality of thermally modified wood. The influence of thermal modification at $180-220{ }^{\circ} \mathrm{C}$ in juvenile wood was equal to mature wood.

\section{ACKNOWLEDGMENTS}

The authors would like to thank the Coordination for the Improvement of Higher Level Personnel (CAPES), Brazil, for financial support.

\section{REFERENCES}

ASTM D-1104. 1978. Standard method for holocellulose in wood. ASTM International, West Conshohocken.

ABnt NBR 7190. 1997. Ações nas Estruturas, Propriedades da Madeira e Dimensionamento nos Estados Limites de Utilização. ABNT, Rio de Janeiro.

Athanázio-Heliodoro JC. 2015. Qualidade da madeira de árvores de Guapuruvu (Schizolobium parahyba (vell.) Blake) com 15 anos provenientes de área de recuperação florestal. MSc. thesis, State University of São Paulo, São Paulo.

Bächle H, Zimmer B, Windeisen E \& Wegener G. 2010. Evaluation of thermally modified beech and spruce wood and their properties by FT-NIR spectroscopy. Wood Science and Technology 44: 421-433.

Bao FC, Jiang ZH, Jiang XM, Lu XX, Luo XQ \& Zhang SY. 2001. Differences in wood properties between juvenile wood and mature wood in 10 species grown in China. Wood Science and Technology 35: 363-375.

BhuiYan TR, Hirai N \& Sobue N. 2000. Changes of crystallinity in wood cellulose by heat treatment under dried and moist conditions. Journal of Wood Science 46: 431-436.

Bortoletto Jr G \& Belini UL. 2002. Produção de lâminas e manufatura de compensados a partir da madeira de Guapuruvú (Schizolobium parayba Blake) proveniente de um plantio misto de espécies nativas. Cerne 8: 1-16.

Calonego FW, Severo ETd \& Assi PP. 2005. Mensuração do comprimento das fibras para a determinação da madeira juvenil em Eucalyptus citriodora. Scientia Forestalis 68: 113-121.

Calonego FW, Severo ETD \& Ballarin AW. 2012. Physical and mechanical properties of thermally-modified wood from Eucalyptus grandis. European Journal of Wood and Wood Products/Holz als Roh- und Werkstoff 70: 453-460.

Calonego FW, Severo ETD \& Latorraca JVF. 2014. Effect of thermal modification on the physical properties of juvenile and mature woods of Eucalyptus grandis. Floresta e Ambiente 21: 108-113.

Engel VL \& Parrotta JA. 2001. An evaluation of direct seeding for reforestation of degraded lands in central São Paulo state, Brazil. Forest Ecology and Management 152: 169-181.

Esteves B \& Pereira H. 2009. Wood modification by heat treatment: a review. BioResources 4: 370-404.

Fengel D \& Wegener G. 1989. Wood: Chemistry, Ultrastructure, Reactions. Gruyter, New York.

IBÁ. 2016. Brazilian Tree Industry. Pöyry Consultoria em Gestão e Negócios Ltda., São Paulo, Brasília.

Lobão MS, Costa DP, Almonacid MAA \& Tomazello Filho M. 2012. Qualidade do lenho de árvores de Schizolobium parahyba var. amazonicum. Floresta e Ambiente 19: 374-384.

Mburu F, Dumarçay S, Huber F, Petrissans M \& Gerardin P. 2007. Evaluation of thermally modified Grevillea robusta heartwood as an alternative to shortage of wood resource in Kenya: characterization of physicochemical properties and improvement of bio-resistance. Bioresource Technology 98: 3478-3486.

Melo RR, Del Menezzi CHS, Souza MR \& Stangerlin DM. 2013. Avaliação das propriedades físicas, químicas, mecânicas e de superfície de lâminas de Paricá 
(Schizolobium amazonicum Huber ex. Ducke). Floresta e Ambiente 20: 238-249.

Richter HG, Tomaselli I \& Moreschi JC. 1974. Estudo tecnológico do Guapuruvu (Schizolobium parahybum) - 1a parte: informe geral sobre as características importantes da espécie. Floresta 5: 26-30.

Severo ETD \& Calonego FW. 2011. Processo de modificação térmica, por irradiação de calor, para a melhora da estabilidade dimensional e da durabilidade biológica de madeira sólida. PI0902/38-8A2. INPI, Rio de Janeiro.

Severo ETD, Calonego FW \& Sansigolo CA. 2012. Physical and chemical changes in juvenile and mature woods of Pinus elliottii var. elliottii by thermal modification. European Journal of Wood and Wood Products/Holz als Roh- und Werkstoff 70: 741-747.

Severo ETD, Calonego FW, Sansígolo CA \& Bond B. 2016. Changes in the chemical composition and decay resistance of thermally-modified Hevea brasiliensis wood. Plos One 11: e0151353.
TAPPI 12 wd-82. 1999. Preparation of Wood for Chemical Analysis. TAPPI, Atlanta.

TAPPI 222 om-98. 1999. Acid-Insoluble Lignin in Wood and Pulp. TAPPI, Atlanta.

Trianosk R. 2010. Avaliação do potencial de espécies florestais alternativas, de rápido crescimento, para produção de painéis de madeira aglomerada. MSc. thesis, Federal University of Parana.

Umar I, Zaidon A, LeE SH \& Halis R. 2016. Oil-heat treatment of rubberwood for optimum changes in chemical constituents and decay resistance. Journal of Tropical Forest Science 28: 88-96.

USDA. 1999. Wood handbook: wood as an engineering material. FPL, Washington.

Zobel BJ \& Van BujJenen JP. 1989. Wood Variation: Its Causes and Control. Springer-Verlag, New York. 